\title{
Lexical Borrowings in the ESL Classrooms in Malaysia
}

\author{
Jantmary Thirusanku ${ }^{1} \&$ Melor Md Yunus ${ }^{1}$ \\ ${ }^{1}$ Faculty of Education, National University of Malaysia, Bangi, Selangor Darul Ehsan, Malaysia \\ Correspondence: Jantmary Thirusanku, Faculty of Education, National University of Malaysia, 7 Lorong Batu \\ Unjur 3B, Bayu Perdana, 41200 Klang, Selangor Darul Ehsan, Malaysia. Tel: 60-192-501-828. E-mail: \\ eambjs@gmail.com
}

Received: June 26, 2013 Accepted: July 25, 2013 Online Published: August 16, 2013

doi:10.5539/ies.v6n9p51

URL: http://dx.doi.org/10.5539/ies.v6n9p51

\begin{abstract}
This paper attempts to show the use of lexical borrowings in ten teaching materials used by the English as Second Language (ESL) teachers in the ESL classrooms in the National Secondary Schools in the Klang district in Selangor, Malaysia. It also discusses the general and pedagogical implications involved in using lexical borrowings. This paper reveals that teaching materials with local context are found to be appealing and interesting to students because of their familiarity and local flavour. Students can instantly recognise the cultural context and respond to the situations and settings. As such they are able to interact with teaching materials in a more meaningful way.
\end{abstract}

Keywords: lexical borrowings, teaching materials, ESL teachers, ESL classrooms

\section{Introduction}

English as an international language is the most widespread medium of worldwide communication (Brumfit, as cited in Thirusanku \& Melor, 2013, p. 18). According to Schreier, Trudgill, Schneider and Williams (2010, p. $1-2$ ) it is an understatement to say that "English is probably the best researched language in the world" (Kyto, Ryden, \& Smitterberg, 2006, p. 1), it should be added that it is "also one of the best-known languages (and there is every reason to assume that this in itself is a consequence of the fact that it is the most widely used language in the world)". According to Smith (1983), it is the principal language of international politics, commerce, technology and aid as well as the language of science and technology. Smith further claims that as an international language, it is not bound to any one culture, and priority is given to communication. There is also no need for non-native users of English to sound like the native-speaker, but simply to use language, which is "appropriate, acceptable and intelligible" (Smith, as cited in Thirusanku \& Melor, 2013, p. 18). The speakers of new Englishes in general do not attempt to imitate the culture of native speakers. This attitude is manifested in the literatures that emerge from these new forms of English. Therefore, English is learnt for the many benefits which are given to the learners.

The key question of whether English is fashioned to adapt and adjust to cultures whose necessities is and has been served by other languages. It is widely accepted that living languages change over time and space. By this measure it can be stated that the English used in environments different from its origin, would adjust and change to suit its new environments. By the same token, traditional English speaking countries and societies can no longer claim sole ownership of the language. More importantly it has been acknowledged that local varieties of English are developing and would continue to do so. Such indigenised varieties are spoken mainly as second languages in many ex-British colonies with multilingual populations. The differences between the new varieties and the standard variety may be viewed from the aspects of phonology, syntax and semantics invoked naturally or otherwise to express new identities (Subramaniam, 2007). Therefore, English in acquiring international identities also acquires "multiple ownership" (Kachru, 1986, p. 31) and the international identities that it has procured are manifested in the form of distinct features in each new variety. These features reside in linguistic choice exhibited by idiosyncrasies of lexis, syntax or style arbitrated by culture, religion, race, nationality, history, politics and a whole range of other socio-economic conditions. In essence, the argument is that new Englishes are linguistically systematic and culturally autonomous (Subramaniam, 2007).

According to Schneider (2011, p. 2-3), English has become localised and indigenised in many different countries. "It is not only viewed as a useful international language, but it fulfils important local functions". As such, it has 
developed local forms and characteristics where people enjoy using it in "their own" way to express regional pride, a sense of belonging to a place with expressions through local culture and language forms.

Malaysian English (ME) is a variety distributed and socially defined within Malaysia. ME has the distinguishing features of simplification and reduction of a non-native variety, as well as the effects of localisation of an acculturated variety. Localisation here means the assimilation of loanwords from the Malaysian languages into the English language, which has resulted in ME. ME, like other varieties of English, is not homogeneous. The variation within ME can be distinguished based on settings, both formal and informal. The formal variety is used by the educated speakers and is used in print media, academic books and discourse. While the informal or colloquial sub-varieties are used in informal situations. The basic features of ME, in terms of phonology, lexis and syntax, are not totally different from the British English (BE). However, these linguistic aspects have been influenced and modified to some extent by the local languages, particularly, the Malay language, Chinese dialects and Indian languages.

\section{Literature Review}

\subsection{Why Borrowings Occur}

In the context of $\mathrm{ME}$ and most varieties of English that have emerged in former British colonies, lexical borrowing is not initiated by native speakers of English. This contradicts the commonly-held perception that only native speakers of the recipient language can be agents of borrowing (Thomason \& Kaufman, 1988) and Winford (2003).

According to Schneider (2003a), the early English-speaking settlers; traders and colonial officers from different regional backgrounds played an important role in borrowings from the languages spoken locally into their English language. As for ME, features such as toponyms, flora and fauna, are still used today. After the British left, borrowing was undertaken by the local community who speak English concurrently with other languages; persons who are bilingual or multilingual in English.

This is in line with Thomason's (2001, p. 68) revised view that "borrowers do not have to be native speakers," and that fluent speakers are as capable as native speakers in using lexical borrowings. Fluency is important as the speaker needs to be familiar with the linguistic structure of a language in order to use external features without disrupting the originality of the language. The features introduced into the recipient language may then be transmitted to other speakers of the community. Features that are relevant to the needs of the community may become permanent additions to the vocabulary of other speakers of the recipient language, whether they are fluent or not. This concept of borrowing will be the theoretical basis for this paper.

Malaysia is a heterogeneous society with three main races that is the Malays, Chinese and the Indians. Malaysia has a unique language setting with rich linguistic diversity. Its multi-ethnic population portrays various customs, beliefs, traditions and of course various religions and languages. Each community has its own mother tongue but there are more than the three main languages.

According to Asmah (1985) the Malay groups mainly speak the Malay language which differs in dialect according to the state. For instance, the Malay dialect used in Negeri Sembilan varies greatly from the dialect used in Johor or Kedah.

The Chinese community in Malaysia uses dialects namely, Cantonese, Hokkien, Hakka and Teochew for social, informal communication. However, Mandarin which is the national language of China is used in formal communication. It is considered as the language of literature and education and used as a form of communication with one another.

The Indian community is the third main ethnic group in Malaysia. About $80 \%$ of them speak Tamil which is the language of Tamil Nadu. The rest of the community speak the languages of the state their forefathers came from for example, Telegu (Andhra Pradesh), Malayalam (Kerala), Kannadam (Karnataka), Punjabi (Punjab) and so on. Even within the Tamil-speaking communities there are variations. The Sri Lankans speak Tamil differently from the others. Therefore the Indians also depict linguistic diversity just like the Malay and Chinese communities.

Therefore, such linguistic diversity leads to inter-language influence which is in contact namely, borrowing. Lexical or phrasal borrowings take place when two or more languages are exposed to each other (Hockett, 1958; Kemmer, 2004). This occurs both ways but mostly asymmetrical whereby more words are transferred from one language to another (Kemmer, 2004). This will only take place when the origin language group is very prestigious and causes more benefits to the economy of the borrowing language group. This shows that the borrowing group looks up to the users and wants to be like the borrowed language group. 
According to Hockett (1958), another cause is the intention of the borrower to be received by a specific community even though he does not look up to or prefer the other language. Since the borrowing language is of less prestige, the number of words borrowed from the dominant language is larger. However, this paper concentrates on borrowings from the less reputable languages into English which is an international language and has a higher status.

Hockett (1958, p. 405) claims that another reason for inter-lingual borrowing to occur is the necessity to "fill in the gap". This is to express ideas and concepts where there are no exact equivalents. Hockett refers to this as the "need-filling motive". This is where the donor language provides terms to new customs, traditions and things in the borrowing language, for instance, the term 'kolam' does not have a similar term in English. Thus, it has to be taken from the donor language, which is Tamil and used as it is.

Furthermore, another reason for borrowing to occur is the convenience factor (Ratnam, 1993). Some words are easily detectable in the donor language than in the borrowing language. For instance, the word 'kampong' is used extensively in ME speech and writings although there is a similar term 'village'. It is due to the fact that 'kampong' is very recognisable or popular compared to 'village' and thus, very easily used. According to Platt, Weber and Ho (1984, p. 91), 'kampong' in ME express a different concept from a European 'village' and it relates to a closely structured community with a definite community life and feeling of belonging. Other examples of words due to convenience factor are 'rotan' (cane), 'adat' (custom), 'taman' (garden) etc. This explains why borrowing takes place from Bahasa Melayu which is less prestigious into English which is a dominant language of the country. However, in the writing process, borrowing is planned and intentional as the writer has time to ponder over what he intends to write.

According to Holmes (2001), borrowing takes place when a speaker of a second language uses a word from his mother tongue when he is unaware of a suitable term in the second language. He also claims that this type of borrowing deals with individual words or nouns and this is because of limited vocabulary.

Ringbom (1983) claims that lexical borrowing deals with a more sophisticated linguistic process which implements the creative analogy element in conquering the semantic aspects. This process also combines various lexical items to accomplish the native language use. Ringbom believes that the speaker must be highly fluent in the language he transfers. He points out that in the spoken or written process, a speaker activates his awareness of other languages and the degree this is done is unknown. He also claims that this is dependent on two factors that are the proficiency of the learner and the gap (actual and detected) between the languages.

According to Crystal (1997), lexical borrowing takes place on the account of the speaker's necessity to outline the identity of his culture with the borrowed language. He further claims that in many countries, the donor language (first language or official language) is less prestigious and the second language is the presiding language globally.

\subsection{Types of Borrowing}

According to Bloomfield (1963) there are two types of borrowing namely, dialect borrowing and cultural borrowing. Dialect borrowing refers to borrowed features from within the same speech area while cultural borrowing refers to borrowed features from a different language. This paper deals with cultural borrowing.

Bloomfield (1963) also claims that cultural borrowing reveals the teachings of one nation to another. Whenever there is cultural borrowing, words or phrases from other cultures used to define the word which is borrowed, are borrowed too (Sapir, 1921).

According to Bloomfield (1963), cultural borrowing is described with relation to the linguistic community based on the domains of geography and politics. Haugen, 1950 (as cited in Bloomfield, 1963, p. 445) claims that "each speech community learns from its neighbours" and the mastered language includes "terms for objects, both natural and manufactured, and patterns of action, such as technical procedures, warlike practices, and religious rites passed from one community to the other".

As stated earlier, cultural borrowing refers to elements that have been borrowed from another language. According to Achebe, 1965 (as cited in Vethamani, 1996) in order to explain one's background, he must use the English language appropriate to the location, schedule and requirement. This can be explained further with an examination of linguistic borrowings.

Sapir (1921) talks about grammatical elements (syntax, inflections and word formation) of how borrowings are dependent on the borrowing language system. He explains that foreign forms may produce their own grammatical relations when there are many foreign forms borrowed from a particular language. He also claims that when numerous borrowings come from a specific language, the non-native form attracts native words by 
acculturation. The speakers who use non-native objects refer to the native names of such objects. If these do not match the native names, the foreign objects are described in native words.

Borrowings are also a part and parcel of the techniques of acculturation and nativisation of a language. According to Lowenberg (1986), borrowings from the Malay language into ME are seen as a plan for adapting Standard English to suit the present situation of Malaysia based on sociology and economy. Borrowings from other languages into English continuously take place in order to meet the requirements of becoming a language of culture, tradition and so on. Since Malaysia consists of various languages and dialects, despite the bilinguals multilinguals also exist. Thus, extensive inter-language effects including borrowing in Malaysia is not an unusual issue.

\section{Teaching Materials used by ESL Teachers in the Malaysian Classrooms}

3.1 Sample 1: Lexical Borrowing - Non-Bumiputera

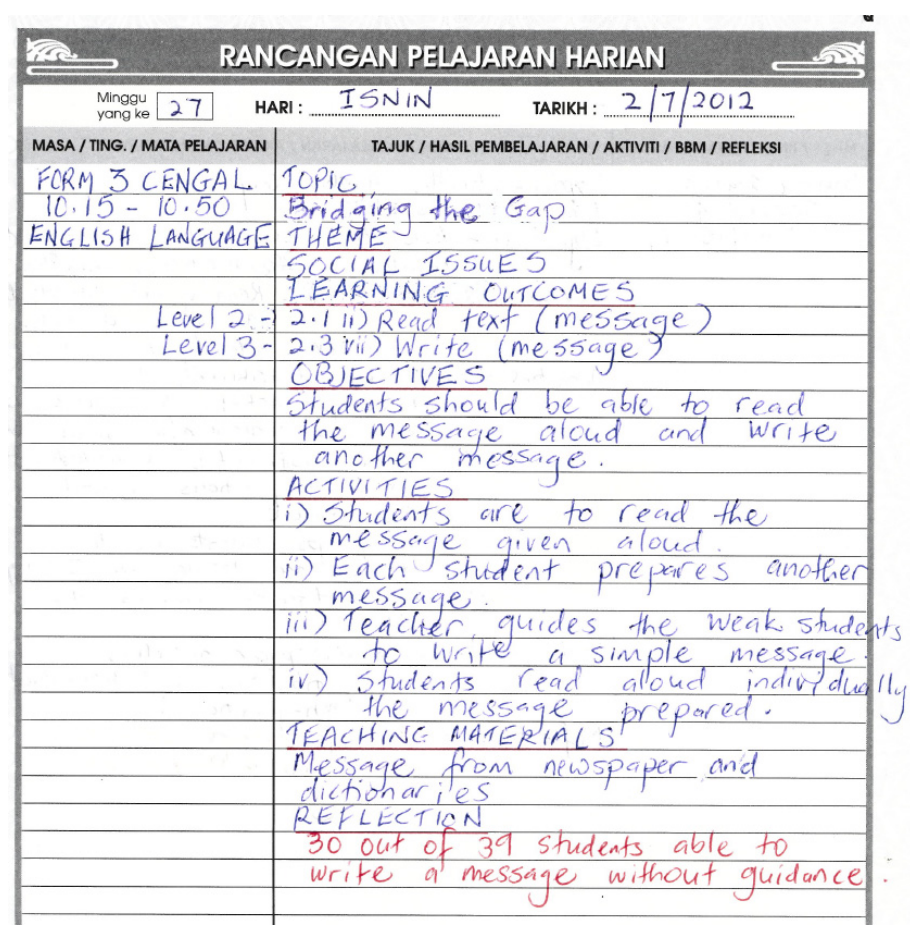

Figure 1.

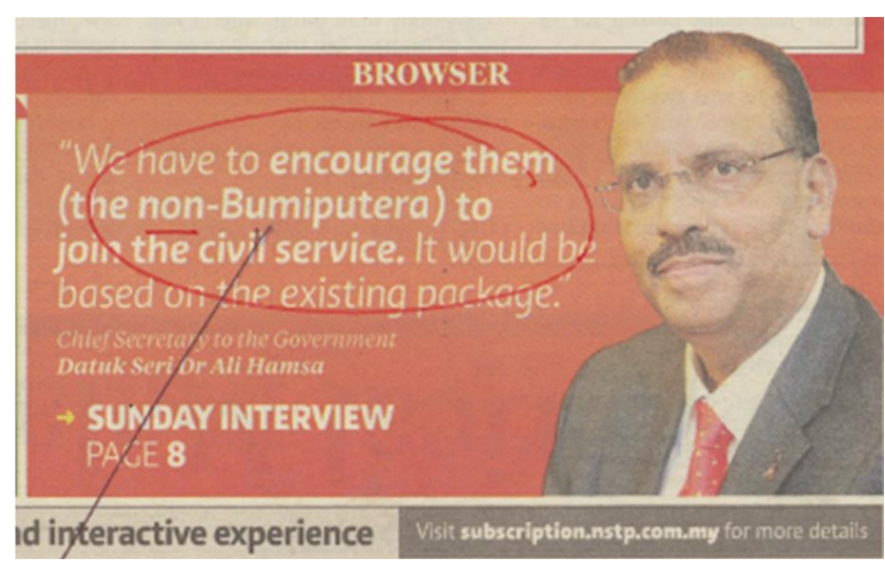

Figure 2.

Source: $\quad$ Written data: message (daily lesson plan)

Sentence: The government is trying to encourage the non-Bumiputera to join the civil service.

Meaning: Non-Bumiputera lacks Bumiputera status but has been established in Malaysia and make up a 
considerable portion of the Malaysian population. Some Chinese and Indian families, known as "straits-born", have resided in Malaysia since as far back as the 15th century. Majority of Malaysia's Chinese and Indian populations are descended from migrants who arrived during the colonial period.

School: $\quad$ SMK Rantau Panjang, Klang, Selangor, Malaysia

ESL Teacher: Indian, male, 44 years old

Date: $\quad 30 / 06 / 2012$

3.2 Sample 2: Lexical Borrowing - Wau Bulan

Reading Comprehension

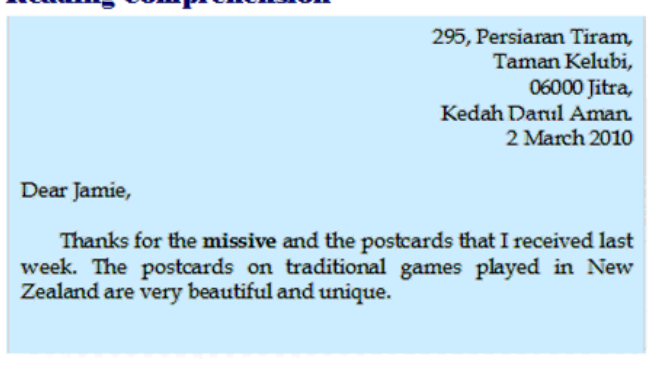

40 continue..

...continuation

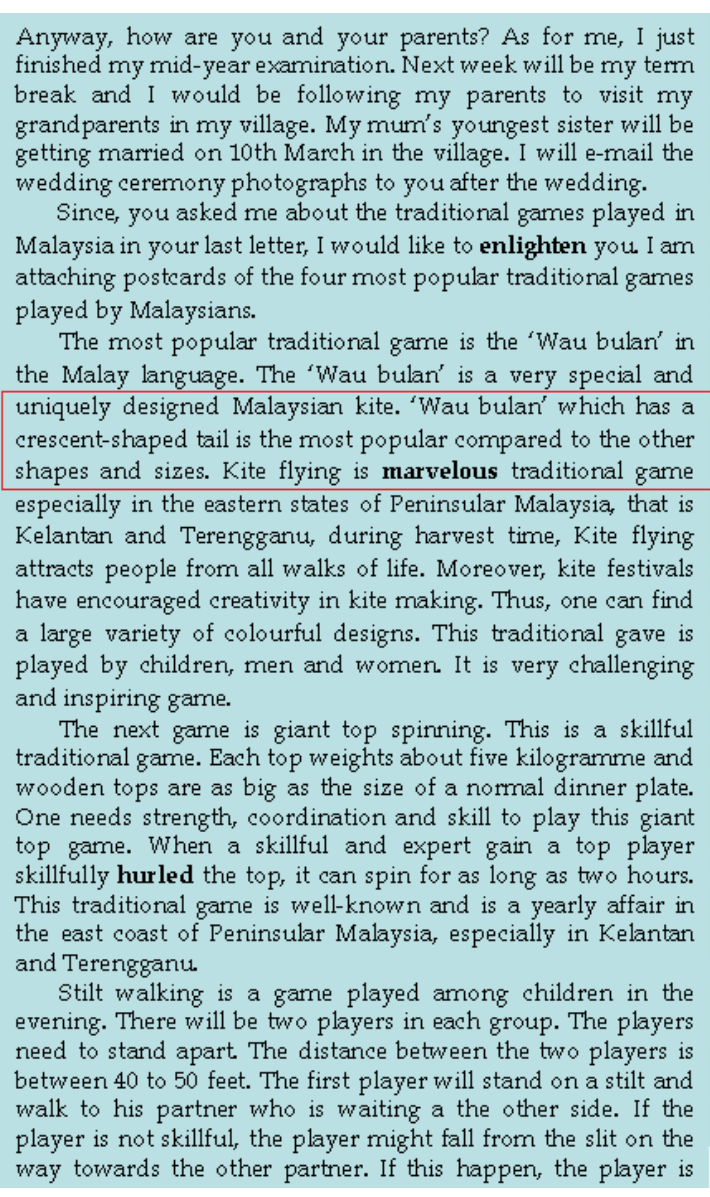

Figure 3.

Source: $\quad$ Written data: textbook

Sentence: Wau bulan which has a crescent-shaped tail is the most popular compared to the other shapes and 
sizes.

Meaning: Wau bulan is a large local kite with a crescent-shaped tail, usually flown (by adults) after the rice harvesting season, between May and July.

School: $\quad$ SMK Sg Kapar Indah, Klang, Selangor, Malaysia

ESL Teacher: Malay, male, 38 years old

Date:

20/03/2012

\subsection{Sample 3: Lexical Borrowing - Ex-Qariah}

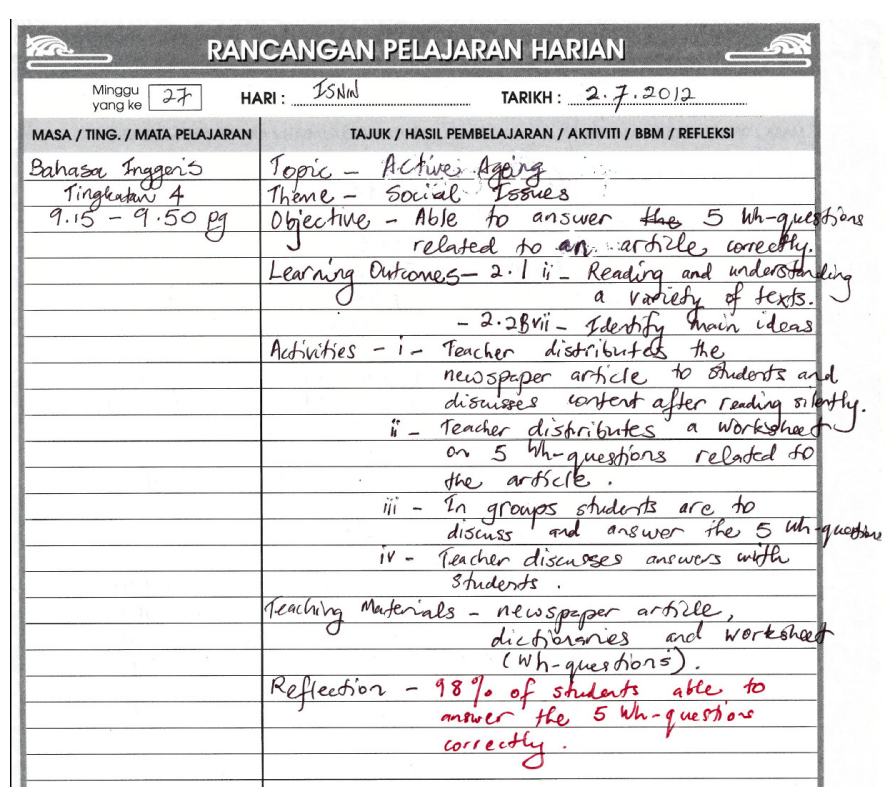

Figure 4.
NEW STRAITS TIMES I PAGE 11

PRIME NEWS

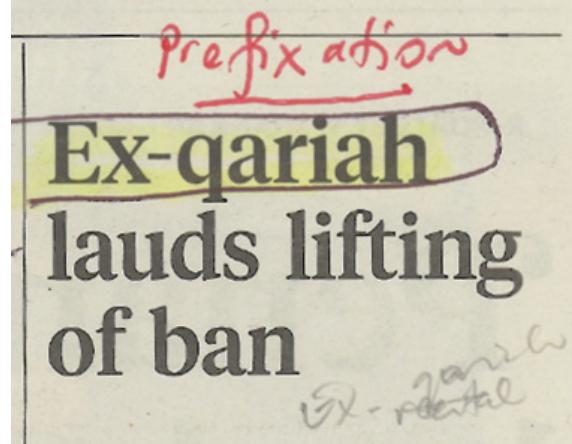

KOTA BARU: Former Quran recital champion Faridah Mat Saman said many budding talents had been wasted during the two decades of the ban on Kelantan women from entering Quran recital competitions.

Faridah, who won the national and international Tilawah Quran competition eight times each, said the ban was a major disappointment for her and other women skilled at reciting the Quran.

"Many qariah (women reciters) had to enter contests by representing other states, which should not have been the case," said the mother of nine at her house in Telipot here yesterday.

She was responding to a report that the state would lift the ban on women taking part in Quran recital competitions, which was introduced in 1990 after Pas took control of the state government.

Faridah said she welcomed the move as this would attract a new generation of women to take part in Quran recitals.

Figure 5. 
Source: $\quad$ Written data: newspaper article (daily lesson plan)

Sentence: $\quad$ Ex-qariah champion Faridah Mat Saman said many budding talents had been wasted during the two decades of the ban on Kelantan women from entering the qariah competitions.

Meaning: $\quad$ Ex-qariah means former woman Quran reciter.

School: $\quad$ Kolej Islam Sultan Alam Shah, Selangor, Malaysia

ESL Teacher: Malay, male, 46 years old

Date: 30/06/2012

3.4 Sample 4: Lexical Borrowing - Panang Nue

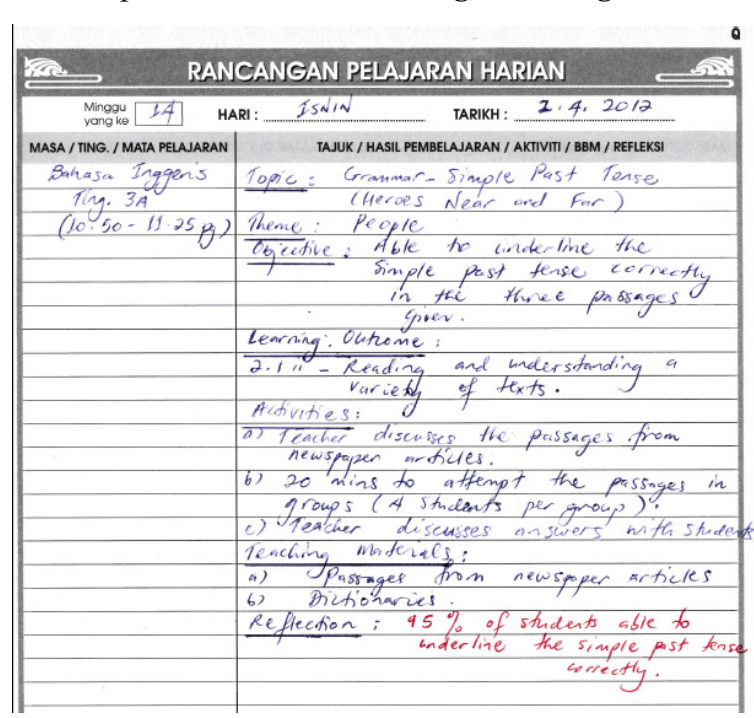

Figure 6.

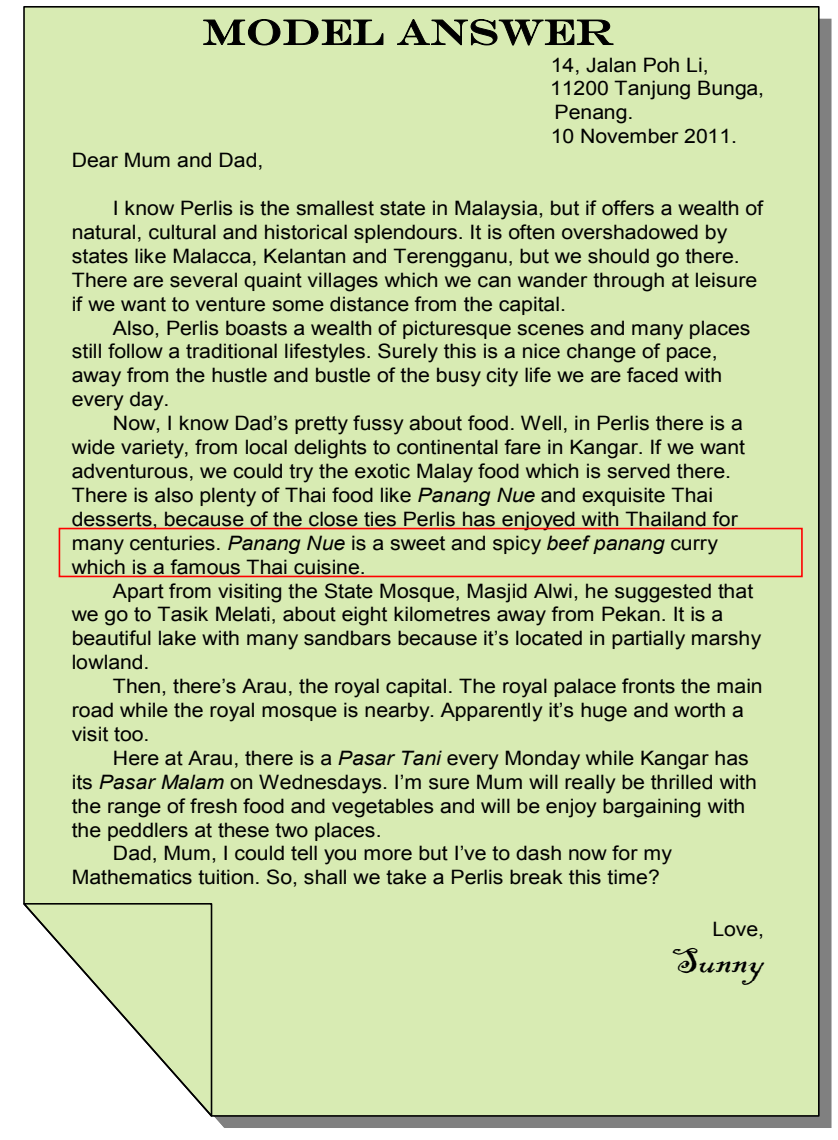

Figure 7.

Source: $\quad$ Written data: daily lesson plan

Sentence: $\quad$ Panang Nue is a sweet and spicy beef panang curry which is a famous Thai cuisine.

Meaning: $\quad$ Panang Nue is a Thai cuisine for sweet and spicy beef curry. Beef panang curry is a sweet and spicy Thai beef curry.

School: $\quad$ SMK Tengku Ampuan Rahimah, Klang, Selangor, Malaysia

ESL Teacher: Malay, female, 35 years old

Date: $\quad 23 / 04 / 2012$ 


\subsection{Sample 5: Lexical Borrowing - Muhibbah}

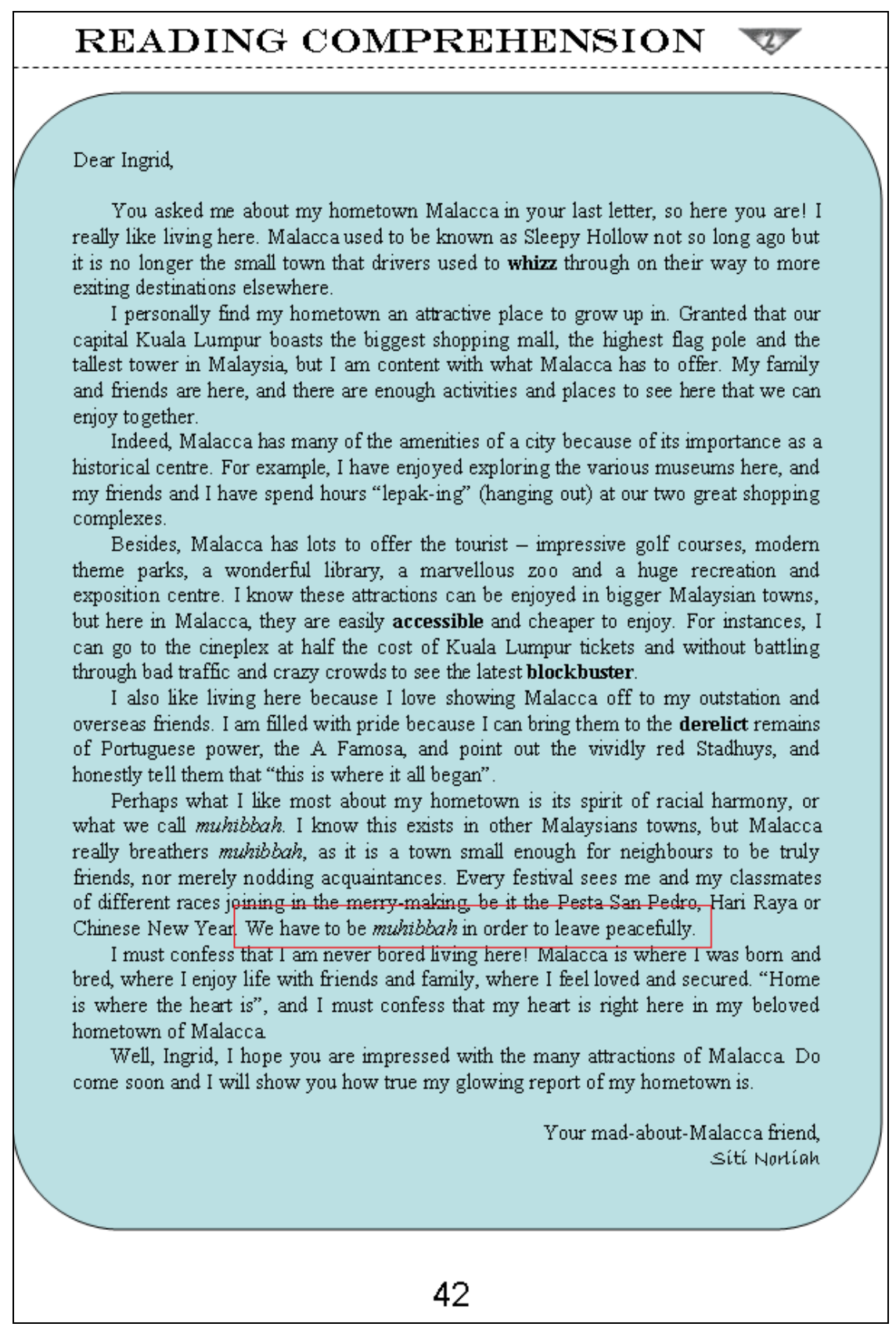

Figure 8 .

Source: Written data: textbook

Sentence: We have to be muhibbah in order to leave peacefully.

Meaning: Muhibbah means harmonious, associated with good will and friendship among different groups of the society.

School: $\quad$ SMK Bandar Baru Sultan Suleiman, Selangor, Klang, Malaysia

ESL Teacher: Malay, female, 39 years old

Date:

$09 / 04 / 2012$ 
3.6 Sample 6: Lexical Borrowing - 1Malaysia
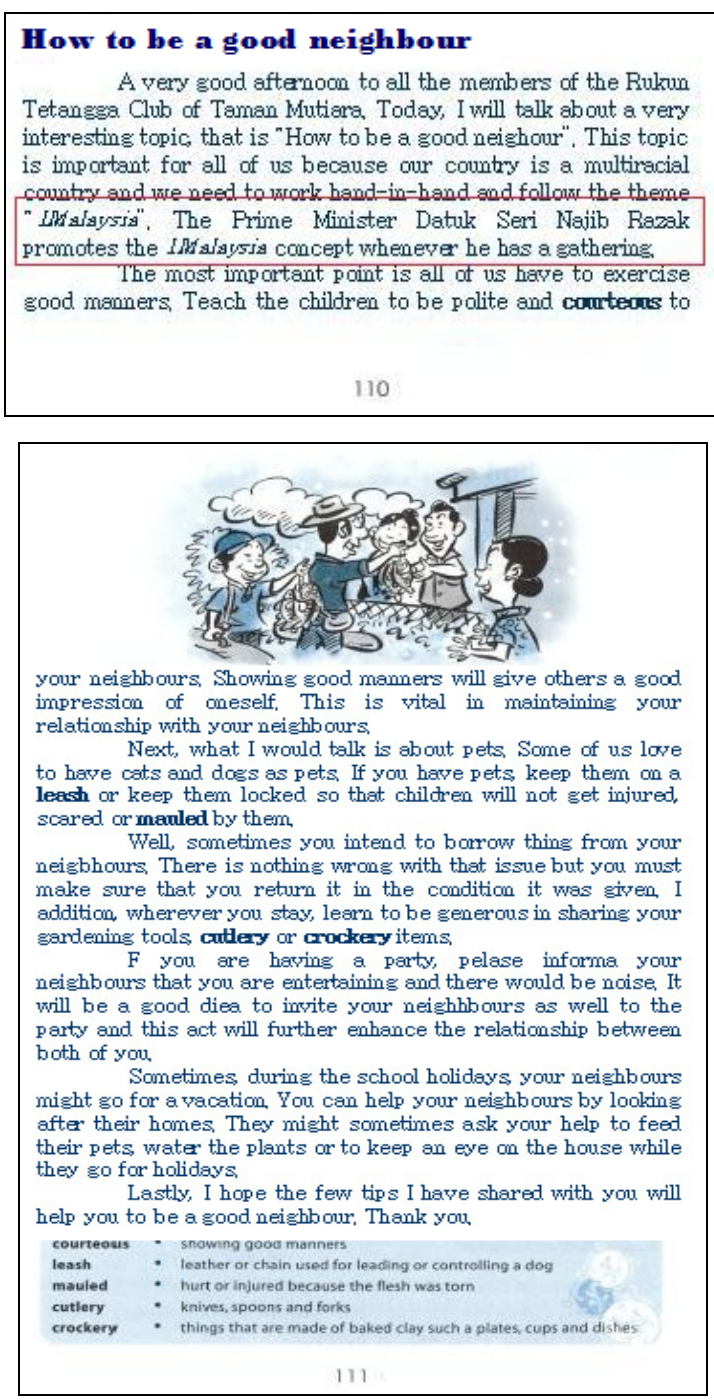

Figure 9.

Source: $\quad$ Spoken data: speech

Sentence: $\quad$ The Prime Minister Datuk Seri Najib Razak promotes the 1Malaysia concept whenever he has a gathering.

Meaning: 1Malaysia (pronounced Satu Malaysia in Malay) is an on-going programme designed by Malaysian Prime Minister Najib Tun Razak on 16 September 2010, calling for the cabinet, government agencies, and civil servants to more strongly emphasise ethnic harmony, national unity, and efficient governance.

School: $\quad$ SMK Pandamaran Jaya, Klang, Selangor, Malaysia

ESL Teacher: Chinese, male, 43 years old

Date:

$21 / 08 / 2012$ 
3.7 Sample 7: Lexical Borrowing - Asar

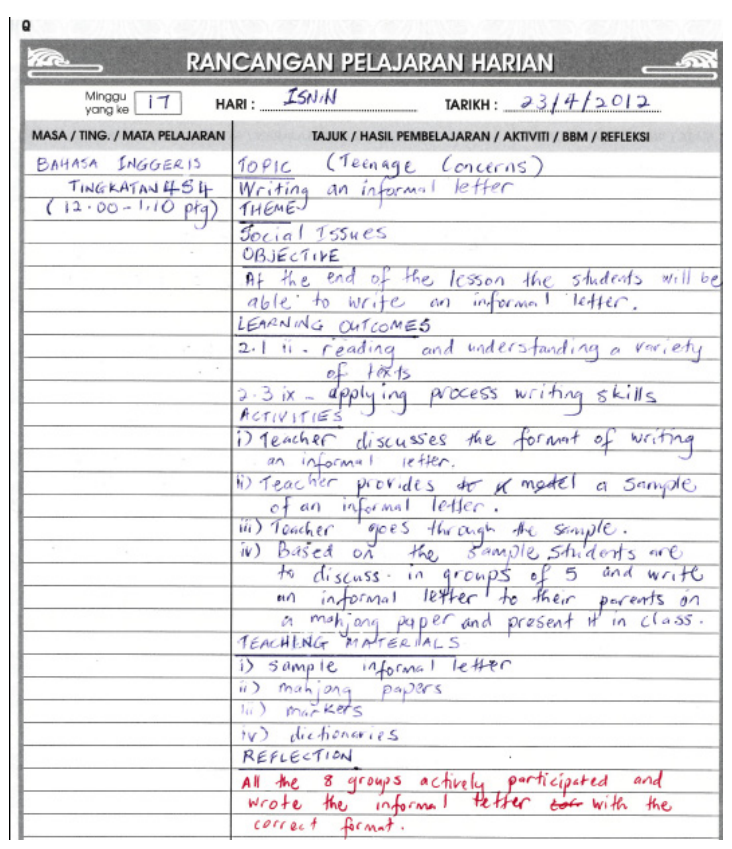

Figure 10.

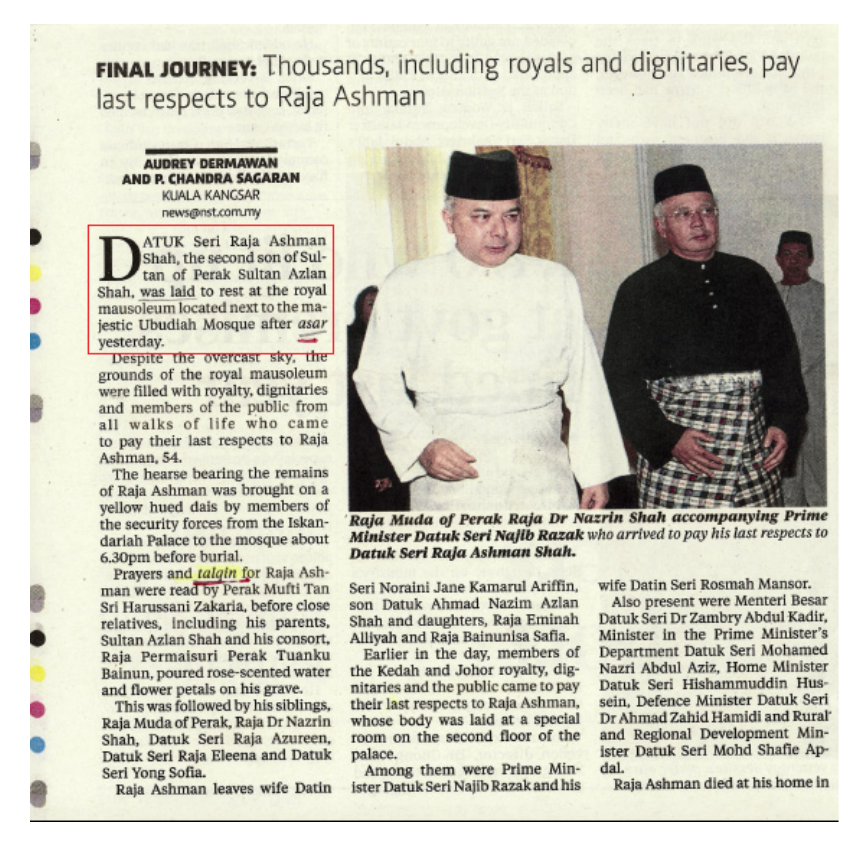

Figure 11.

Source: $\quad$ Written data: newspaper article (daily lesson plan)

Sentence: $\quad$ Datuk Seri Raja Ashman Shah, the second son of Sultan of Perak Sultan Azlan Shah, was laid to rest at the royal mausoleum located next to the majestic Ubudiah Mosque after asar yesterday.

Meaning: Asar means one of the 5 Muslim prayers. This asar prayer time is around $4.20 \mathrm{pm}$.

School: $\quad$ SAM Nurul Iman, Klang, Selangor, Malaysia

ESL Teacher: Malay, female, 47 years old

Date: $\quad 31 / 03 / 2012$

3.8 Sample 8: Lexical Borrowings - Paratha, Lontong

\begin{tabular}{|l|}
\hline Choral Speaking Script 'Technology' \\
(Robotic voice) \\
You -are -now -entering -the -digital -world \\
The - world -of - gadgets - and -androids \\
Where -hi -tech -is -in -control \\
Where -robot -is -in -charged \\
And .... and...... and....... \\
(Sound of machine breakdown) \\
. \\
. \\
Laptop is simply solid, sleek and sassy \\
Now, with the laptop in hand, \\
You can browse the internet practically anywhere.. \\
At the trendy uptown bistro and cafe \\
while sipping your creamy latte espresso \\
mmuuahh.. mama mia.. \\
\hline Just as paratha is a favourite among the Indians (solo) \\
lontong is a favourite among the Malays (solo) \\
\hline . \\
. \\
One day robots can be our fiends, our buddies, \\
Like ASIMO, the Japanese humanoid robot, \\
Which, or should I say who, can speak, dance and move like human. \\
(Robotic Voice) \\
And -with -that -we -bid -sayonara -and -thank -you. \\
\hline
\end{tabular}

Figure 12. 
Source: $\quad$ Spoken data: language activity (Choral Speaking)

Sentence: Just as paratha is a favourite among the Indians, lontong is a favourite among the Malays.

Meaning: $\quad$ Paratha is a flatbread that originated in the Indian subcontinent.

Lontong is a dish made of compressed rice cake in the form of a cylinder wrapped inside a banana leaf and boiled, then cut into small cakes served with peanut sauce-based dishes or accompaniment to coconut milk based soups.

School: $\quad$ SMK Batu Unjur, Klang, Selangor, Malaysia

ESL Teacher: Indian, female, 38 years old

Date:

05/09/2012

3.9 Sample 9: Lexical Borrowings - Teh Tarik, Mamak Coffee Shops

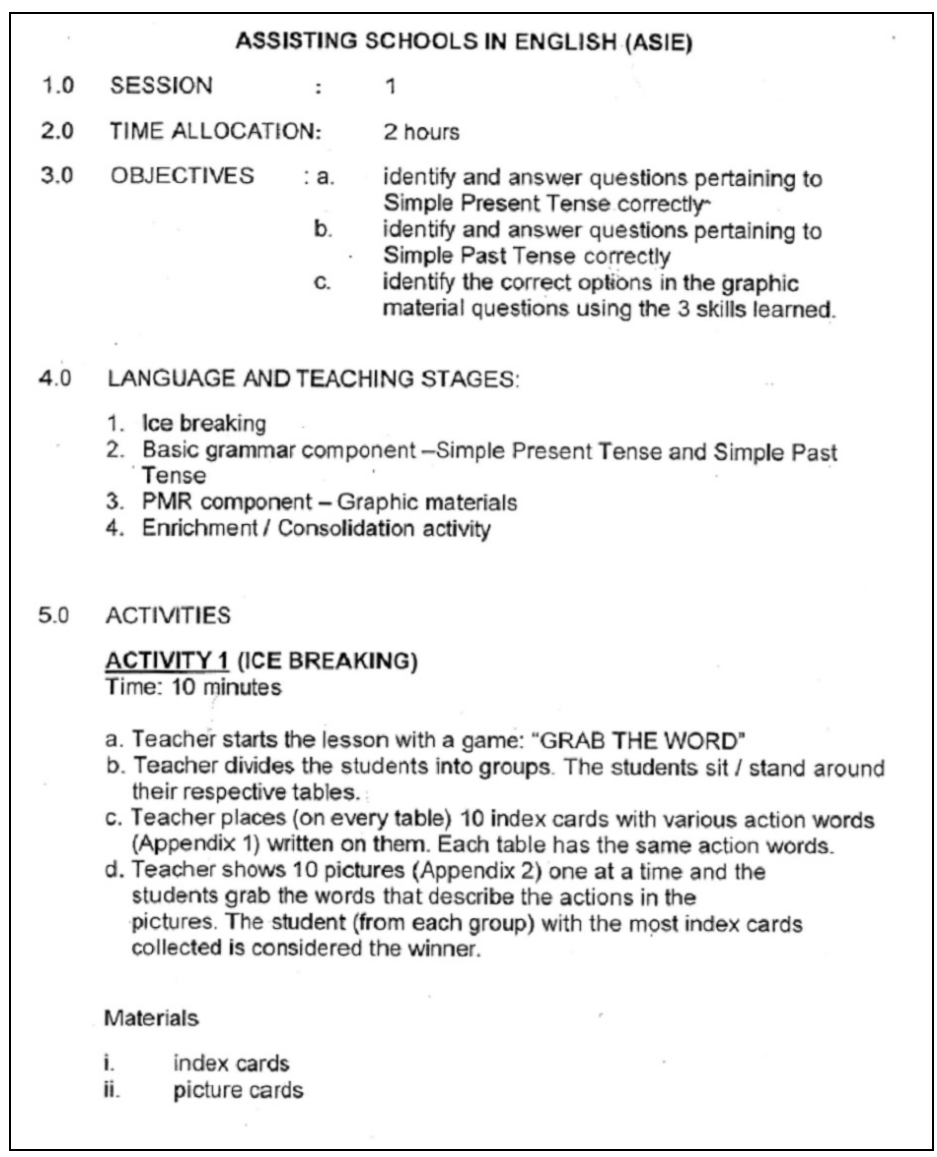

Figure 13. 


\section{ACTIVITY 2}

Time: 30 minutes

a. Teacher briefly explains 3 common functions (with examples) of Simple Present Tense

i. to show a habitual action

ii. for instructions and directions

iii. to show factual statement

b. Individual Work - Teacher introduces Grammy Box (Appendix 3) to the students and shows them how to make simple sentences using simple present tenses.

c. Teacher monitors and facilitates students attempting to construct sentences using the Grammy Box.

d. Teacher displays a substitution table (Appendix 4) and calls out on students to construct sentences

e. Teacher distributes worksheets (Appendix 5) of various simple present tense exercises.

f. Teacher discusses the answers with the students.

Materials:

i. Grammy Box

ii. Work sheets (Simple Present Tense)

\section{ACTIVITY 3}

Time: 30 minutes

a. Teacher briefly explains the common function (with examples) of Simple Past Tense

- to express an action that took place in the past

b. Teacher distributes Bingo card game to every group. (Appendix 6)

c. Teacher displays fill-in-the-gap sentences (Appendix 7) and students need to cross out the correct answers. The student, who manages to get all the answers correctly, says 'Bingo' and he/she is the winner.

d. Individual Work - Teacher introduces Grammy Box (Appendix 8) to the students and shows them how to make simple sentences using simple past tense.

e. Teacher monitors and facilitates students attempting to construct sentences using the Grammy Box.

f. Teacher distributes worksheet (Appendix 9).

g. Teacher discusses the answers with the students.

Materials:

i. Grammy Box

ii. Bingo Cards

iii. Computer

iv. Worksheets (Simple Past Tense)

Figure 14 


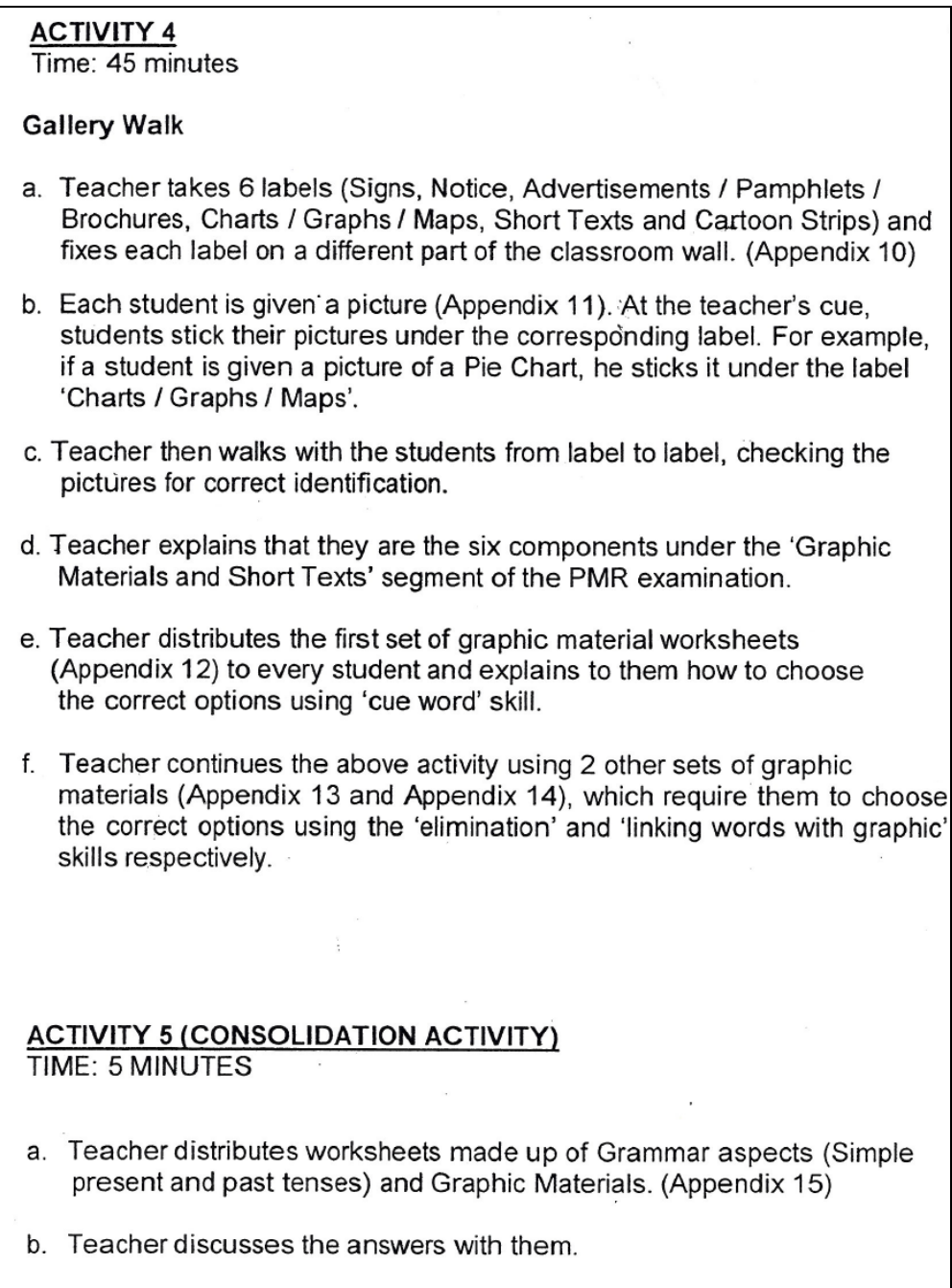

Figure 15.

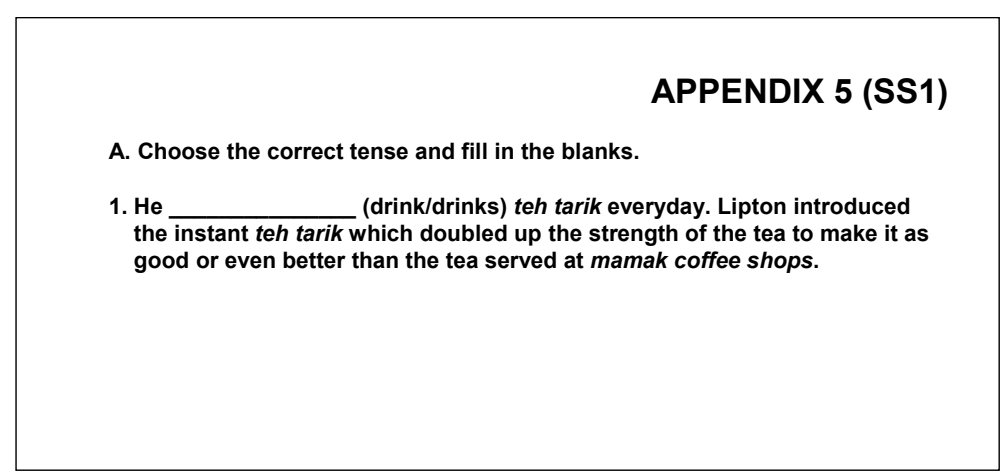

Figure 16.

Source: $\quad$ Written data: ASIE lesson plan

Sentence: $\quad$ Lipton introduced the instant teh tarik which doubled up the strength of the tea to make it as good or even better than the tea served at mamak coffee shops.

Meaning: $\quad$ Teh tarik - literally "pulled tea" is a hot Malaysian tea beverage which can be commonly found in restaurants, outdoor stalls and kopi tiams in southeastern Asian countries like Malaysia. Its name is derived from the pouring process of "pulling" the drink during preparation. It is made 
from black tea and condensed milk.

Mamak coffee shops - coffee shop or small restaurant run by mamak or Tamil Muslims. Mamak coffee shops tend to be popular among Malaysian youths as hang out spots, due to cheap food and beverages being served 24 hours a day, 365 days a year. People of all races, religions and ages frequent mamak coffee shops to gossip or catch a late-night football game while enjoying a cup of hot teh tarik. No other eatery has quite as much cultural significance in Malaysia.

School: $\quad$ SMK Raja Mahadi, Klang, Selangor, Malaysia

ESL Teacher: Indian, female, 29 years old

Date:

28/03/2012

3.10 Sample 10: Lexical Borrowing - Jubah

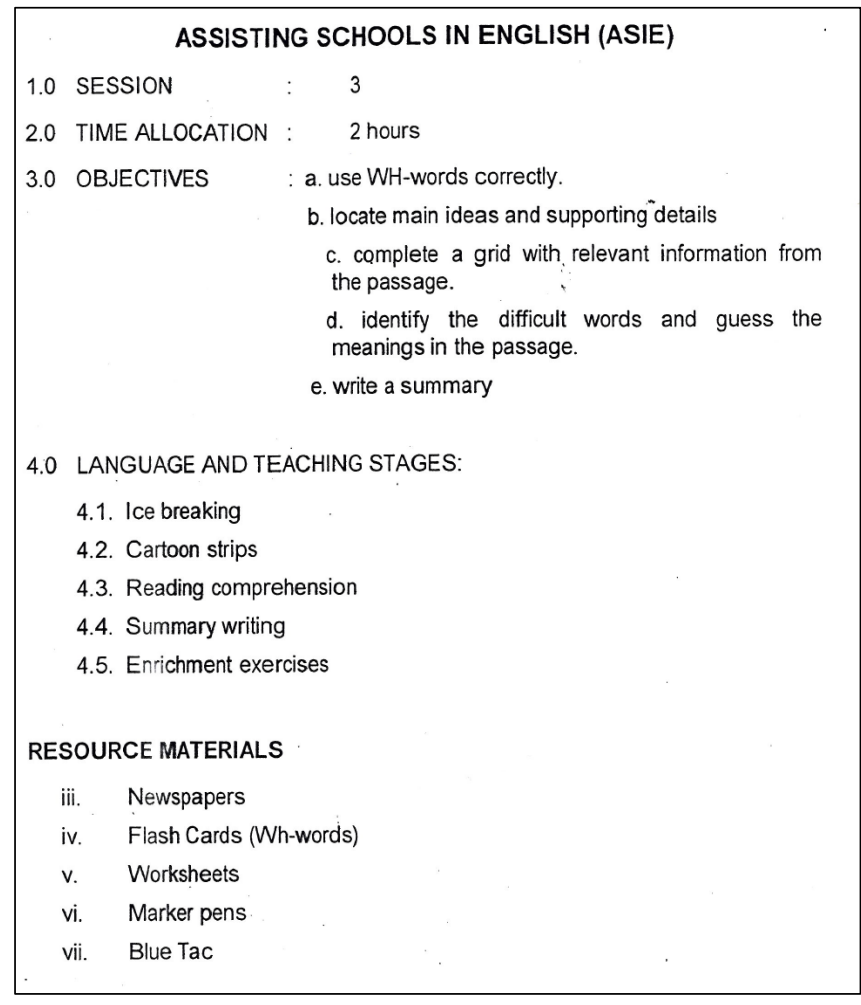

Figure 17.

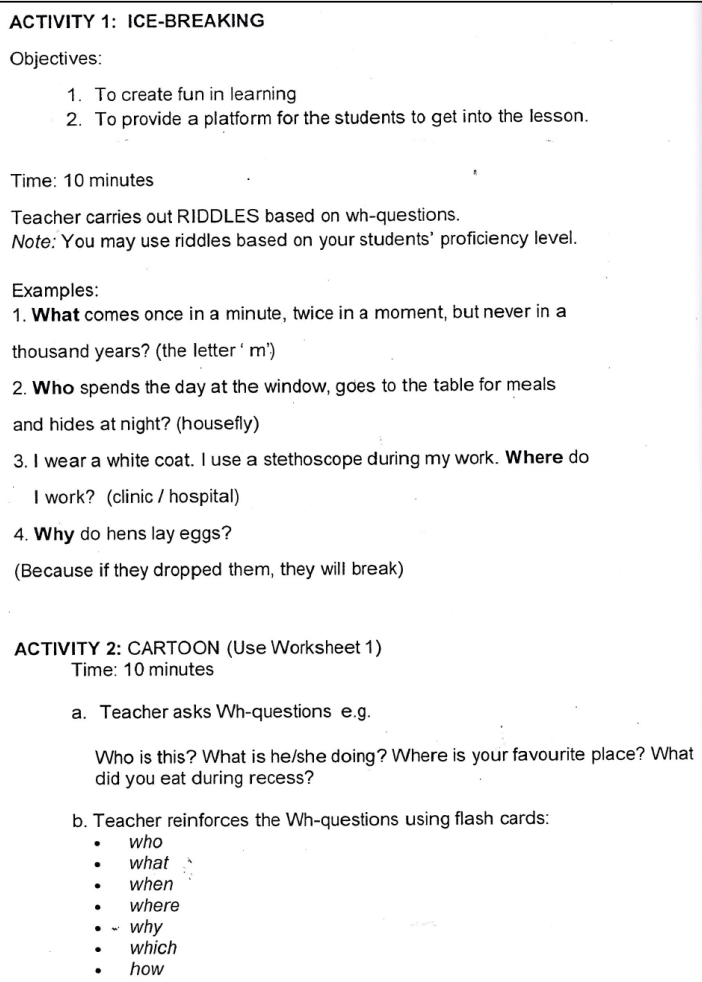

Figure 18. 


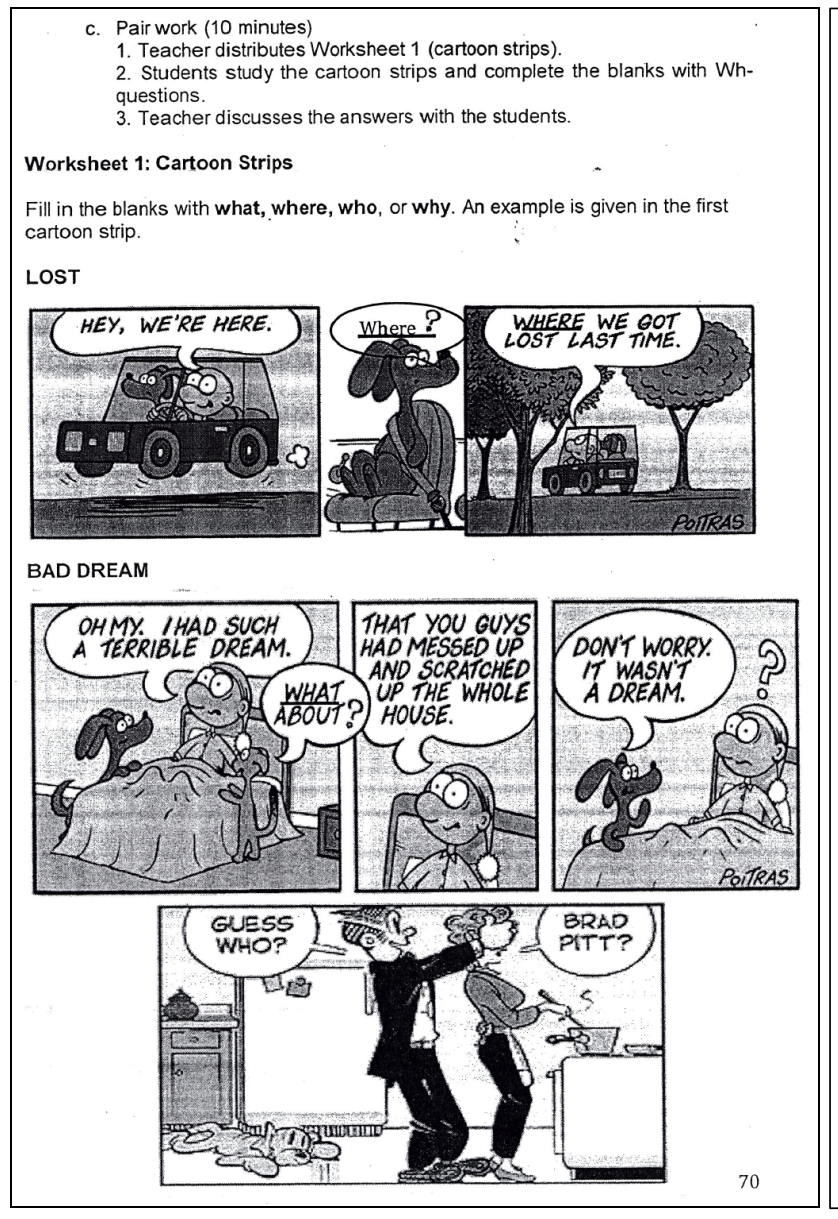

Figure 19.
ACTIVITY 3: READING COMPREHENSION / SUMMARY

Time: 45 minutes

a. Group work (10 minutes)

Use Worksheet 2 [Newspaper Article]

i. Teacher gives students a newspaper article and worksheet 2.

ii. Teacher tells students to read the article and complete the table given.

iii. Teacher confirms the answers.

\section{b. Pair work (10 minutes)}

1. Teacher distributes worksheet 3 [Brochure].

2. Students read the text and answer the questions given.

3. Teacher discusses the answers with the students.

\section{Pair work (10 minutes) SUMMARY WRITING}

1. Read the text in worksheet 4.

2. Identify 5 content points based on the questions given.

3. Teacher confirms the points and gets the students to copy the points in the worksheet.

4. Students write the summary using the grid given.

\section{ACTIVITY 3: NEWSPAPER ARTICLE}

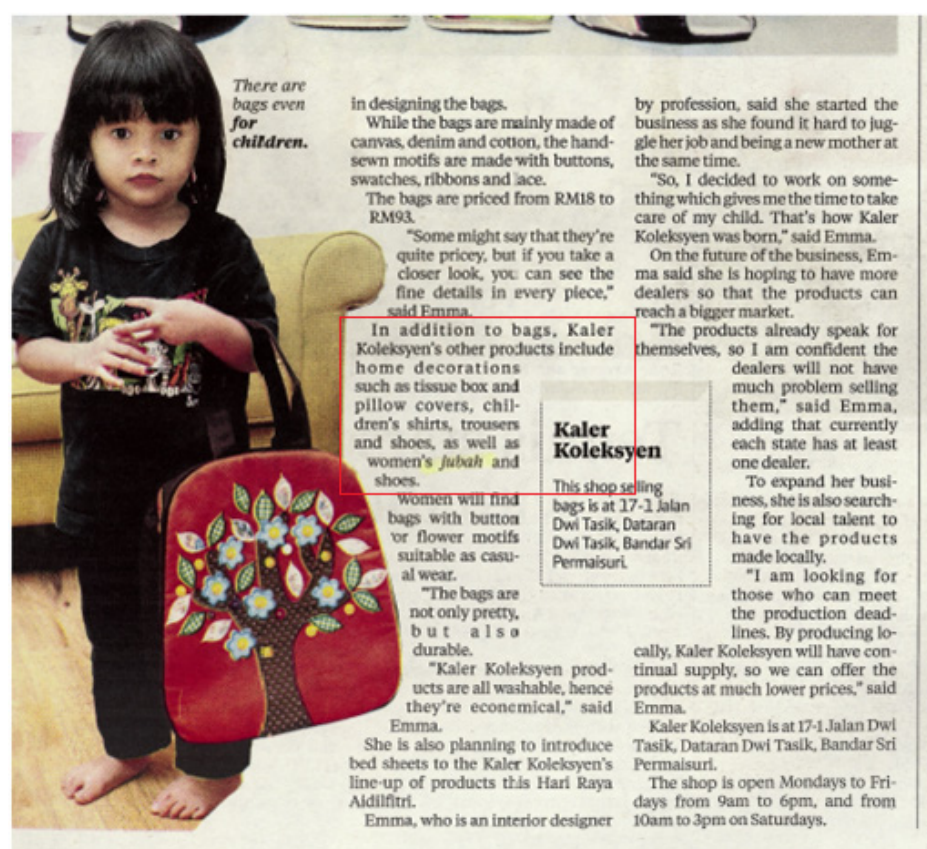

Figure 21. 
Source: $\quad$ Written data: newspaper article (ASIE lesson plan)

Sentence: In addition to bags, Kaler Koleksyen's other products include home decorations such as tissue box and pillow covers, children's shirts, trousers and shoes, as well as women's jubah and shoes.

Meaning: Jubah is a woman's dress normally used in the Middle East by Muslim women.

School: $\quad$ SMK Raja Mahadi, Klang, Selangor, Malaysia

ESL Teacher: Malay, female, 39 years old

Date: $\quad 22 / 03 / 2012$

\section{General Implications}

The borrowings are because there are no exact equivalents in the English language to replace the Malay and Indian terms. Besides that, the nativised lexical items are used when discussing local issues for various other reasons. The direct borrowing of terms in the field of culture, tradition and culinary is to ensure inter translatability. In short, the lexical items are borrowed directly to ensure that the linguistic and cultural identities of the borrowed terms are preserved.

The borrowed terms have developed a range of meanings that are an extension of the original meanings as well as new meanings. Such a combination would in all likelihood enhance and enrich the language and culture. The contact of English with Malaysian socio-cultural norms and patterns has generated new socio-cultural meanings owing to an attempt to make English and its users, feel at home in a Malaysian socio-cultural milieu. Malaysia is a country with three main ethnic groups; Malay, Chinese and Indian. Each of these groups is rich with their own cultures and languages. In many ways the practice of these cultures and the languages are encouraged to show unity and harmony. Each group is free to practice its culture and use their language. The above scenario would certainly create a situation where it is rich with words from each other's language.

It has been proven beyond doubt that the pragmatic consequences of the presence of many languages in a particular context involve lexical borrowing, language mixing, code switching and lect switching (Richards, 1983). Due to the different lifestyles of this multicultural and multilingual society, there are loans from contact languages. No matter how eloquent one is with English, "there is the inevitable departure from other varieties of well-educated English" (Wong, 1981, p. 97). The use of these loan words serves to establish rapport among speakers. These loan words are used in everyday speech. Hence, this adds to the uniqueness of Malaysian English.

The process of 'domesticating' English for localised purposes demands that the non-native bilingual postcolonial writer is able to express his thought patterns in a culture-specific language within the context of situation. Achebe (1969) says that this process is solely achieved based on instinct than formal judgement. Kachru (1987, p. 128) in setting up some hypotheses concerning bilingual grammar, states that it has to be captured in terms of what sociolinguists call "verbal repertoire" or "code repertoire", with specific reference to each speech community. These repertoires include characteristics of code mixing, code switching and the adaptation of stylistic and discoursal strategies available to the bilingual. These distinctive features may be seen as limiting or extending the text, depending on how one looks at it and what one considers as linguistic innovations. The interpretation of such creativity demands "an identification with the literary sensibility of the bilingual tune with ways of saying and levels of new meaning" (Kachru 1987, p. 130).

The lexical items from the Malay language dominate the number of borrowings compared to the lexical items from the Indian languages. The contemporary socio-political dominance of the Malay people and their language has resulted in the tendency, among scholars of world Englishes, to concentrate on what Morais (2001, p. 35) refers to as "the overriding influence of Malay" on ME. In Malaysia, the Malay language is the main medium of instruction in schools.

A study by Marlyna (2006) reveals that despite the Malaysians having exposed to the English language since the age of 7, the year they entered primary schools, the speech act of apology displayed influences of the Malay socio-cultural rules. Thus, this is one of the many examples that show the influence of the Malay language in the lives of the Malaysians.

The number of parents who studied in English medium schools and use English at home has deteriorated. The English used by the Malay-medium Malaysians is to create situations closer to daily communication, for example, to convey messages, to make and receive calls, interviews for jobs, to give instructions and to sell things. It is on the verge between EFL and ESL (Platt \& Weber, 1980). The influence of their cultural elements is evident in the written and spoken discourse of the Malaysians. Thus, the usage of the lexical items shows that the 
Malaysian English as Second Language (ESL) teachers accept the Malay language, Chinese dialects and the Indian languages in a variety known as Malaysian English.

Malaysian English speakers, on the whole, view ME positively, not only does it reflect their own culture, many of its most distinctive and therefore, most divergent linguistic features "are sociolinguistically necessary to mark diverse styles, identities and registers in the non-native socio-cultural contexts of ...Malaysia" (Lowenberg, 1984, p. 17-18). An indication of their loyalty towards ME is how some of them react to the use of American or British or Australian English accents by other members of their community, the latter are often regarded as snobbish or arrogant (Tongue, 1979). Under such circumstances, the pull to integrate borrowed features of the English language must surely be tempered by the need to maintain the autonomy of a variety of English that has come to be accepted as the community's very own.

\section{Pedagogical Implications}

In Malaysia, the importance of English has always been stressed, especially to attain knowledge and for international communication. Though the importance has been stressed and education policies have been implemented to improve the standard of English, there have been numerous complaints from ESL teachers, the government and private sectors about the poor command of English among local students. With the above situation, would it be right to use these lexical items in ESL classes in Malaysia? By incorporating these socio-culturally influenced lexical features, are we not compromising international intelligibility? Where should the line be drawn in ESL classes?

According to Gill (1993), it is English spoken by an educated Malaysian with an unmarked accent (possibly the Standard Malaysian English) which is favoured as a pedagogical model. It is clear that the need for a Standard Malaysian English arises in language teaching but not as a prestige variety. It is important that we acknowledge that there is a ME which has its own lexical items. It is a normal sociolinguistic phenomenon. As Gill (1994, p. 70) puts it, "One cannot reverse the sociolinguistic tidal wave of language change - giving rise to phrases, words, structures which are so different from general standards that only Malaysians understand them. A linguistic researcher's delight but a language teacher's nightmare."

These lexical items are functional and serve the communicative needs of Malaysians. Students are exposed to these lexical items in their everyday lives. They use them with their friends and family members when they speak English (ME). They also hear others using them. This situation can be equated to what Kabakchy (1983, p. 229) sees in the Soviet Union, "Traditionally EFL - teaching in the Soviet Union sticks to the norms of Standard British English. However, as soon as speakers find it necessary to apply English to their local situations, they cannot help overstepping Queen's English conventions."

The other reality is the lack of opportunity and motivation to use English outside the ESL classrooms in Malaysia. Bahasa Melayu (BM) as the national language is frequently used in many occasions to interact among Malaysians. Whatever is learned within the four walls of the ESL classroom may not be relevant to many students who seem to survive outside the classroom without using "proper English" (Anthonysamy, 1997, p. 107). Asmah Haji Omar seems to have hit the nail on its head by saying that teaching the students how to express themselves in English to buy stamps or in getting a taxi to the railway station will be futile exercise, because they surely find it easier to do such things in BM and are better understood by their respondents. She goes on to say, communicative competence in the language will fall into disuse the moment the make believe classroom situation ends at the completion of the allocated hour (as cited in Platt \& Weber, 1980).

With these realities, we have to decide on an appropriate approach and teaching materials. It is essential that we make decisions as to what we consider appropriate and what we should encourage our learners to aspire to. A pragmatic approach needs to be adopted to face the challenge of developing a generation proficient in the language. We have to take what is advantageous for us from the West, (the exonormative norms) sprinkle it with what is appropriate and acceptable for our situation (Gill, 1994). In that case, the government does not have to spend so much money on foreign teachers, the focus should be on guiding our teachers to perform better based on an endonormative model.

What is appropriate and acceptable in our ESL classes? A guideline would be the aims stated in the teacher's handbook for the Post 1970 Primary School English Syllabus, issued by the Ministry of Education (1971, p. 3):

Malaysians are learning English increasingly as a language of international communication. The aim should therefore continue to be to teach children to speak in such a way that they will be understood not only by fellow-Malaysians but also by speakers of English from other parts of the world.... 
... international intelligibility does not imply that pupils should necessarily speak exactly like Englishmen: there would not be sufficient time to achieve this, nor is it necessary.

The Cabinet Committee Report on the Review of the Implementation of the Education Policy 1979 states that the teaching of English is to enable learners to use English in everyday situations and work situations as well as to pursue higher education. At present, English is still taught for the purpose of higher education and the workplace. English is the language of Information Communications Technology (ICT) as well as the language for establishing international relations in a borderless world. To enable our learners to access information on the Internet and other electronic media as well as to network with the students in other parts of the country and abroad, it is important that they are proficient in the language. Such proficiency will also help learners to read and listen to academic, professional and recreational materials and to speak in seminars and conferences.

The English curriculum for primary schools is designed to provide learners with a strong foundation in the English language. Learners will then be able to build upon this foundation and use the language for various purposes. The development of learners' linguistic ability is in keeping with the goals of the National Education Philosophy and the Education Act of 1996 which seek to documents, the curriculum is explained in greater detail for each year of schooling. There is one set of specifications for each primary level schooling. The English language syllabus for primary schools aims to equip learners with basic skills and knowledge of the English language so as to enable them to communicate, both orally and in writing, in and out of school.

Therefore, we have to consider both the Malaysian realities and the English the nation needs, when we decide to allow the usage of nativised lexical items in our ESL classes (Anthonysamy, 1997). Some of the changes embodied in Malaysian English are a result of characteristics brought to it by the new language users, their relationships to each other, and their purposes. Changes inscribed in these new varieties are products of real needs and realities in new language speaking contexts (Subramaniam, 2007).

Considering the realities and the needs of our country, there should be "language awareness and language appropriateness" (suggested by Mc Kay in Tickoo, 1991, p. 46) when an ESL class uses nativised lexical items. It would be 'foolish' to ignore these lexical items in ESL classes. Of course the approach to create language awareness and show language appropriateness would differ according to students' proficiency, motivation and maturity.

Materials with local context are found to be appealing and interesting to students because of their familiarity and local flavour. Lee (1994) has given some of the advantages of using culturally familiar materials. She found that students can instantly recognise the cultural context and respond to the situations and settings. They are able to interact with materials in a more meaningful way. In activities which require their input, students can cull from their own experiences and cultural heritage. One can find a lot of local based materials from local newspapers (articles, reports, letters, etc.), magazines, television shows (English talk shows), video clips and others. ESL teachers themselves are good examples as this paper itself shows the types and extent of use of nativised lexical items by ESL teachers. These materials could also be pictures related to Malaysian scenes, articles related to students' everyday lives, namely clothes, food, musical instruments, artefacts, stamps, songs and so on. A teacher has to choose suitable materials for students according to age, background, interest, proficiency and also have a clear objective.

Lexical items represent the culture, values and the people familiar to the students. By using culture related lexical items in teaching materials, students in ESL classes will be able to associate themselves with the language. They will be motivated to be engaged with it, make it their own and something of relevance to their reality rather than somebody else's. In this way learners will begin to feel as well as speak the language.

English language teachers in Malaysia should allow students to use nativised lexical items to generate and elaborate their ideas. Once students have used these lexical items to express their ideas and opinions and are geared on the lesson or topic, teachers can then take the opportunity to explain the usage of these lexical items in ME and the 'standard norm'. They can be taught the Standard English equivalent if there is one and the appropriate use of the nativised English lexical items. There should be language awareness in usage of these lexical items. This strategy can act as reinforcement because the standard form is now related to the lexical items that are functional in the student's daily life. According to Tickoo (1994, p. 54):

So to must (attention be paid to) approaches that help make a planned use of L1 resources (including interlingual translation) in the teaching of English. Even more useful may prove to be resources that bilingual teachers and learners who share one or more 'local' language bring to the English classroom.

Most students in rural areas in Malaysia have very low motivation. They do not see the relevance of learning 
English. Jakobovits (1969) in his study on motivational and attitudinal factors relevant to foreign language study, claims that a failure to achieve intended goals is due to the fact that the language is not perceived to be relevant to students' educational needs (as cited in Nair, 1994, p. 116). By using authentic materials which allow them to use nativised lexical items (these lexical items could differ regionally) they will be able to relate English to their 'kampong' life style, values and beliefs. English teachers will be able to engage the learners' attention. Students can then be taught how to convert the nativised lexical forms into the standard form when this is required. When the differences are pointed out, students will be able to see appropriateness in usage and this awareness will help students to build communicative competence. Isn't that what language 'learning' is all about?

Krashen's comprehensible input (as cited in Tickoo, 1994, p. 54) notion should be used in this light. According to Krashen, comprehensible input can only be effective when the affective filter is down (as cited in Harmer, 1983, p. 14). One way of lowering this barrier is not to insist on early accurate reproduction. Creating a relaxed and familiar language learning atmosphere must be seen as an essential condition for ESL classes. In other words local languages particularly nativised lexical items should "work in cooperation rather than in competition" in ESL classes (Tickoo, 1994, p. 54).

Trudgill (1975) feels the "elimination" approach is dangerous because language is socially symbolic. When nativised lexical items are rejected, it also means rejecting all those like him who he identifies with and values. This could also cause resentment towards the learning of English (as cited in Platt \& Weber, 1980, p. 198-200). By acknowledging nativised lexical items and its usage, teachers will be able to introduce the standard forms as 'alternatives' rather than 'replacements'. Sharwood Smith argues convincingly that both implicit knowledge about language (as a result of comprehensible input) and explicit knowledge (as the result of 'consciousness raising') may stimulate the acquisition process (as cited in Harmer, 1983, p. 12).

The well planned nativised English lexical items can be effectively used to the advantage of ESL classes to gear students' attention and interest. Teachers should relate to appropriateness of lexical items in language use and show the relevance of the standard form. In order to do that teachers must have knowledge of language awareness and appropriateness. They should know the correct usage of the standard form and the nativised variation of the lexical items. The evidence in this paper proves that the ESL teachers regardless of ethnic group, gender and age are fully aware of the Malaysian English lexis as they themselves use the nativised variations of the lexical items.

\section{Conclusion}

Teachers of ESL classes have to make sure that a teaching programme does not abandon standards. All methods used in ESL classes should gear students to the appropriate usage of the standard forms. It is the integrative part of any language teaching programme that it has a goal in the form of language norms (Platt \& Weber, 1980). We must not get into a situation in ESL classes in Malaysia where there is acceptance of 'anything goes' as long as the message gets across.

Sociolinguists have for some time now been aware that no matter how hard English teachers and curriculum planners may strive, it is the people namely, the nation, region, district and so on who will decide in the end how they wish to speak. Language goes along with the ways of the society. By acknowledging the existence and the pragmatics of Malaysian English lexis, ESL teachers can utilise them to motivate students to learn the language. In fact, with a little bit of creativity, ESL classes can be made interesting with the usage of nativised lexical items.

\section{References}

Achebe, C. (1965). Transition. English and the African write, 4(18), 27-30. http://dx.doi.org/10.2307/2934835

Achebe, C. (1969). Hope and Impediments: Selected Essays 1965-1987. London: Heinemann.

Anthonysamy, J. (1997). Lexico-semantic variations in Malaysian English. Unpublished Masters Thesis, University of Malaya, Kuala Lumpur.

Asmah Haji Omar. (1985). The Language Policy of Malaysia. A Formula for Balanced Pluralism. Pacific Linguistics, 9, 39-49.

Bloomfield, L. (1963). Language. London: George Allen and Unwin Limited.

Brumfit, C. (1982). English as an International Language I: What Do We Mean by 'English'? In Brumfit, C. (Ed.), English for International Communication. Oxford: Pergamon Press.

Crystal, D. (1997). English as a Global Language. Cambridge: Cambridge University Press. 
Gill, S. K. (1993). Standard and pedagogical norms for teaching English in Malaysia. World Englishes, 12(2), 223-238. http://dx.doi.org/10.1111/j.1467-971X.1993.tb00023.x

Gill, S. K. (1994). The English that we have and the English the Nation Needs - A Dilemma or a Peaceful Co-existence. Proceedings of the International English Language Education Conference (Intelec), 66-77. Kuala Lumpur, Malaysia.

Harmer, J. (1983). Krashen's Input Hypothesis and the Teaching of EFL. World Englishes, 3(1), 11-15. http://dx.doi.org/10.1111/j.1467-971X.1984.tb00562.x

Haugen, E. (1950). The Analysis of Linguistic Borrowing. Language, 26(April-June), 210-231. http://dx.doi.org/10.2307/410058

Hockettt, C. F. (1958). The Conditions of Borrowing. A Course in Modern Linguistics. New York: The Macmillan Company. http://dx.doi.org/10.1111/j.1467-1770.1958.tb00870.x

Holmes, J. (2001). An Introduction to Sociolinguistics. London: Pearson Education Limited.

Kabakchy, V. V. (1983). Striking a Balance between Universal and Local. World Englishes, 2(4), 229-231. http://dx.doi.org/10.1111/j.1467-971X.1983.tb00700.x

Kachru, B. B. (1986). The Alchemy of English: The Spread, Functions, and Models of Non-native Englishes. Urbana, Chicago: University of Illinois Press.

Kachru, B. B. (1987). The Bilingual's Creativity: Discoursal and Stylistic Strategies in Contact Literatures. In Smith, L. E. (Ed.) Discourse Across Cultures - Strategies in World Englishes. Hertfordshire: Prentice Hall, pp. 125-140.

Kemmer, S. (2004). Loanwords. Retrieved September 5, 2004, from http://www.ruf.rice.edu/ kemmer/Words/loanwords.html

Kyto, M., Ryden, M., \& Smitterberg, E. (Eds.) (2006). Nineteenth - Century English: Stability and Change. Cambridge: Cambridge University Press. http://dx.doi.org/10.1017/CBO9780511486944 PMCid:PMC1489446

Lee, S. K. (1994). Designing Materials with Local Colour and Feel. Proceedings of the International English Language Conference (Intelec), 386-389. Kuala Lumpur, Malaysia.

Lowenberg, P. H. (1984). English in the Malay Archipelago: Nativization and its functions in a Sociolinguistic Area. Michigan: Bell \& Howell Company.

Lowenberg, P. H. (1986). Sociolinguistic Context and Second-Language Acquisition: Acculturation and Creativity in Malaysian English. World Englishes, 5(1), 71-83. http://dx.doi.org/10.1111/j.1467-971X.1986.tb00641.x

Marlyna Maros. (2006). Apologies in English by Adult Malay Speakers: Patterns and Competence. International Journal of Languages, Culture and Society, 19.

Mc Kay, S. L. (1991). Variation in English: What role for Education? In Tickoo, M. L. (Ed.), Languages and Standards: Issues, Attitudes, Case Studies. Singapore: SEAMEO Regional Language Centre.

Ministry of Education, Malaysia. (1971). A Teacher's Handbook for the Primary School English Syllabus. Kuala Lumpur: Dewan Bahasa and Pustaka.

Morais, E. (2001). Lectal varieties of Malaysian English. In Vincent Ooi (Ed.), Evolving Identities: The English Language in Singapore and Malaysia. Singapore: Times Academic Press.

Nair, A. B. (1994). Motivation without Need: A Case for Promoting Malaysian English. Proceedings of the International English Language Conference (Intelec), 114-121. Kuala Lumpur, Malaysia.

Platt, J., \& Weber, H. (1980). English in Singapore and Malaysia. Kuala Lumpur: Oxford University Press.

Platt, J., Weber, H., \& Mian, L. H. (1984). The New Englishes. London: Routledge \& Keegan Paul.

Ratnam, P. (1993). Lexical Borrowing from Malay to English. Unpublished Masters Thesis, University of Malaya, Kuala Lumpur.

Richards, J. C. (1983). Singapore English: Rhetorical and Communicative Style. In Kachru, B. B. (Ed.), The Other Tongue: English Across Cultures. Urbana: University of Illinois Press.

Ringbom, H. (1983). Borrowing and Lexical Transfer. Applied Linguistics, 4(3), 207-212. http://dx.doi.org/10.1093/applin/4.3.207 
Sapir, E. (1921). How Languages Influence Each Others Language. New York: Harcourt. Brace and World Inc.

Schneider, E. W. (2003a). Evolutionary patterns of New Englishes and the special case of Malaysian English. Asian Englishes, 6, 44-63.

Schneider, E. W. (2011). English Around the World An Introduction. Cambridge: Cambridge University Press.

Schreier, D., Trudgill, P., Schneider, E. W., \& Williams, J. P. (Eds.) (2010). The Lesser-Known Varieties of English An Introduction. Cambridge: Cambridge University Press. http://dx.doi.org/10.1017/CBO9780511676529

Smith, L. E. (Ed.). (1983). Readings in English as an International Language. London: Pergamon.

Subramaniam, G. (2007). The Changing Tenor of English in Multicultural Postcolonial Malaysia. 3 L Journal of Language Teaching, Linguistics and Literature, 13, 1-19.

Thirusanku, J., \& Melor Md. Yunus. (2013). Malaysian English - A Distinct Variety. Internet Journal of Language, Culture and Society, 37, 18-29.

Thomason, S., \& Kaufman, T. (1988). Language Contact, Creolization, and Genetic Linguistics. Berkeley, CA: University of California Press.

Thomason, S. (2001). Language Contact: An Introduction. Washington, D.C: Georgetown University Press.

Tickoo, M. L. (1994). Towards a Model for ESL Systems: An Educational Option. Proceedings of the International English Language Conference (Intelec), 52-56. Kuala Lumpur, Malaysia.

Tongue, R. K. (1979). The English of Singapore and Malaysia. Singapore: Eastern Universities Press.

Vethamani, M. E. (1996). Character Presentation and Interaction: Styles of Minority Discourse in the Malaysian English Novel. Unpublished Ph.D Thesis, University of Nottingham.

Winford, D. (2003). An Introduction to Contact Linguistics. Oxford: Blackwell.

Wong, I. (1981). English in Malaysia. In L. E. Smith (Ed.), English for Cross-cultural Communication. London: Macmillan.

\section{Copyrights}

Copyright for this article is retained by the author(s), with first publication rights granted to the journal.

This is an open-access article distributed under the terms and conditions of the Creative Commons Attribution license (http://creativecommons.org/licenses/by/3.0/). 